\title{
Occurrence of poultry coccidiosis in different management systems in Thrissur, Kerala*
}

\author{
(iD) \\ Pooja G. Mankani ${ }^{* \star}$, Asha Rajagopal' ${ }^{2}$ K. Devada ${ }^{3}$, \\ M. N. Priya ${ }^{2}$, I. S. Sajitha ${ }^{4}$ and R. Karthika ${ }^{1}$ \\ Department of Veterinary Parasitology, College of Veterinary and Animal Sciences, \\ Mannuthy, Thrissur- 680651 \\ Kerala Veterinary and Animal Sciences University, Kerala, India.
}

Citation: Pooja, G. M., Asha, R., Devada, K., Priya, M. N., Sajitha, I. S. and Karthika, R., 2021. Occurrence of poultry coccidiosis in different management systems in Thrissur, Kerala. J. Vet. Anim. Sci. 52(3): 303-307. DOI: https://doi.org/10.51966/jvas.2021.52.3.303-307

Received:21.12.2020

Accepted: 20.01.2021

Published: 30.09.2021

\section{Abstract}

Coccidiosis is one of the most prevalent and economically important parasitic diseases caused by the infection with Eimeria species contributing to major economic losses of poultry industry worldwide. In this study, occurrence of Eimeria spp. in chicken reared under different management systems was studied. A total of 300 faecal samples from chicken were collected from six organised poultry farms and six backyard poultry units in and around Thrissur, Kerala. Out of this, 167 faecal samples were from organised farms and 133 from backyard poultry units. All the samples were artificially sporulated and examined for studying the oocysts morphology and morphometry. Out of 167 samples from organised farms 52 were found to be positive for Eimeria spp. while 61 out of 133 samples from backyard poultry were positive. The overall occurrence of Eimeria spp. in chicken from 12 different areas in and around Thrissur was 37.66 per cent (113/300). The species of Eimeria identified on morphological examination were E. tenella, E. necatrix and E. maxima. The occurrence rate of E. tenella was found to be significantly higher $(46.01 \%)$ compared to E. necatrix (39.82\%) and E. maxima (14.15\%). The rate of occurrence of Eimeria spp. infection was significantly higher in backyard poultry (45.86\%) compared to that in organised farms (31.13\%).

Keywords: Eimeria species, chicken, organised farms, backyard poultry.

The role of poultry industry has been significant in the socio-economic development of the country. The economics of poultry industry is often adversely affected by the faulty management of the farms and outbreak of different diseases. Avian coccidiosis caused by apicomplexan parasites of the genus Eimeria, is a major menace for poultry industry causing production losses, high mortality

"Part of MVSc thesis submitted to Kerala Veterinary and Animal Sciences University, Pookode, Wayanad, Kerala

1. MVSc Scholar

2. Assistant Professor

3. Professor and Head (Retd.)

4. Assistant Professor and Head (i/c), Department of Veterinary Pathology

${ }^{*}$ Corresponding author: poojamankani7@gmail.com

Copyright: (C) 2021 Pooja et al. This is an open access article distributed under the terms of the Creative Commons Attribution 4.0 International License (http://creativecommons.org/licenses/by/4.0/), which permits unrestricted use, distribution, and reproduction in any medium, provided the original author and source are credited. 
and morbidity rates. Seven distinct species of the genus Eimeria with different degrees of pathogenicity are recognised in chicken viz., Eimeria tenella, E. necatrix, E. maxima, $E$. acervulina, E. brunetti, E. mitis and E. praecox. Some species of Eimeria are highly pathogenic causing severe haemorrhagic enteritis with high mortality in young birds, whereas other species are slightly or moderately pathogenic. During an outbreak of coccidiosis, the identification of the infecting species is usually done by considering clinical signs, sporulation time, oocyst morphology and morphometry. The identification of Eimeria species infecting chicken has important implications in studying the epidemiology as well as in disease management. Hence, the present study was undertaken to study the occurrence of Eimeria spp. in chicken reared under different systems of management.

A total of 300 faecal samples were collected from chicken reared in organised poultry farms and backyard poultry units in and around Thrissur district of Kerala during the period from June 2019 to December 2020. Out of this, 167 samples were from organised farms and 133 from backyard poultry units. In organised farms, the birds were maintained in deep litter system or cage system, fed with commercial feed and routinely vaccinated against viral diseases. The birds in backyard poultry units were maintained in free range system and were not routinely vaccinated.

The faecal samples were examined by sedimentation and floatation techniques following standard protocols (Soulsby, 1982). Morphological identification of the different Eimeria spp. in chicken was done by a combination of morphological features of the oocysts (shape, presence or absence of the micropyle) and morphometry as per Soulsby (1982). The oocysts were artificially sporulated in 2.5 per cent potassium dichromate and the sporulation time was recorded in each case. The occurrence rate of Eimeria spp. in chicken and the influence of different systems of management on the occurrence were statistically analysed by Chi square test using SPSS version 24.0.
The overall occurrence of Eimeria spp. in chicken from 12 different areas in and around Thrissur was 37.66 per cent (113/300). On statistical analysis, the occurrence rate of coccidiosis in different areas was found to be significantly different $(p<0.01)$ (Table 1$)$. The three species of Eimeria were identified based on morphological features, viz., E. tenella, $E$. necatrix and E. maxima (Fig. 1). The oocysts of $E$. tenella and E. necatrix were ovoid in shape whereas that of E. maxima were broadly ovoid. On morphometry, E. tenella oocysts measured $21 \times 18.25 \mu$ with shape index of 1.15 , while $E$. necatrix oocysts measured $23.77 \times 22.05 \mu$ and had a shape index of 1.07 and E. maxima oocysts was $28 \times 22.5 \mu$ in size with shape index of 1.24 (Table 2). This concurs with the observations of Khaier et al. (2015) who reported the mean size of $E$. tenella oocyst to be $19.63 \times 17.02 \mu$ with a shape index of 1.15 . Jadhav et al. (2011) observed the mean values of $E$. necatrix oocyst measurement to be 13.2 to $22.5 \mu$ length and 11.0 to $18.7 \mu$ width. AlGawad et al. (2012) observed the mean size of $E$. maxima oocyst to be $29.9 \times 23.8 \mu$ with a shape index of 1.25. Similarly, in a study conducted in Tamil Nadu by Rao et al. (2013), the mean morphometric values recorded were $22 \times 18 \mu$ for E. tenella oocysts, $20.8 \times 17.5 \mu$ for E. necatrix and $31.19 \times 18.5 \mu$ for E. maxima. The average sporulation time of $E$. tenella, $E$. necatrix and E. maxima oocysts was 48-72 h which was in accordance with Soulsby (1982).

On morphological identification $E$. tenella was found to be the most predominant species with an occurrence rate of 46.01 per cent followed by $E$. necatrix (39.82 per cent) and E. maxima (14.15 per cent) (Table 3). On statistical analysis using Chi square test, the occurrence rate of $E$. tenella was found to be significantly higher compared to the other two species $(p<0.01)$. The findings agree with many of the previous reports. Eimeria tenella was found to be the most prevalent species of Eimeria in poultry in a previous study conducted by Gigi George (1997) in Kerala. Similarly, Bhaskaran et al. (2010) also reported the incidence of $E$. tenella to be higher when compared to E. necatrix and E. praecox in Tamil Nadu. In the studies conducted in different farms 
Table 1. Occurrence of Eimeria spp. in chicken in and around Thrissur

\begin{tabular}{|c|c|c|c|c|}
\hline Area & $\begin{array}{c}\text { No. of samples } \\
\text { examined }\end{array}$ & No. positive & $\%$ positive & $p$ value \\
\hline \multicolumn{5}{|c|}{ Organised Farms } \\
\hline Poomala & 22 & - & - & \multirow{7}{*}{0.0036} \\
\hline Pattikkad & 20 & 12 & 60 & \\
\hline University Poultry Farm, Mannuthy & 32 & - & - & \\
\hline Viruppaka & 40 & 22 & 55 & \\
\hline Pazhuvil & 28 & 07 & 25 & \\
\hline Changarakkulam & 25 & 11 & 44 & \\
\hline Total & 167 & 52 & 31.13 & \\
\hline \multicolumn{5}{|c|}{ Backyard Poultry Units } \\
\hline Kunnamkulam & 30 & 18 & 60 & \\
\hline Arangali & 14 & - & - & \\
\hline Thalikkulam & 20 & 17 & 85 & \\
\hline Madakkathra & 20 & - & - & \\
\hline Kuttattukulam & 23 & 15 & 65.21 & \\
\hline Amballur & 26 & 11 & 42.30 & \\
\hline Total & 133 & 61 & 45.86 & \\
\hline Overall Total & 300 & 113 & 37.66 & \\
\hline
\end{tabular}

Table 2. Morphology, morphometry and average sporulation time of Eimeria spp. in chicken

\begin{tabular}{|l|c|c|c|c|c|}
\hline Species & $\begin{array}{c}\text { Shape of the } \\
\text { oocyst }\end{array}$ & Micropyle & $\begin{array}{c}\text { Mean size of } \\
\text { oocyst }(\boldsymbol{\mu m})\end{array}$ & $\begin{array}{c}\text { Shape } \\
\text { index }\end{array}$ & $\begin{array}{c}\text { Avg. } \\
\text { sporulation } \\
\text { time (hrs) }\end{array}$ \\
\hline E. tenella & Ovoid & Absent & $21 \times 18.25$ & 1.15 & $48-72$ \\
\hline E. necatrix & Ovoid & Absent & $23.77 \times 22.05$ & 1.07 & $48-72$ \\
\hline E. maxima & Broadly ovoid & Absent & $28 \times 22.5$ & 1.24 & $48-72$ \\
\hline
\end{tabular}

Table 3. Occurrence of Eimeria species in chicken

\begin{tabular}{|c|c|c|c|c|}
\hline Species & $\begin{array}{c}\text { No. of samples } \\
\text { examined }\end{array}$ & No. positive & $\%$ positive & p-value \\
\hline E. tenella & \multirow{3}{*}{113} & 52 & 46.01 & \multirow{3}{*}{$<0.0001^{\star}$} \\
\hline E. necatrix & & 45 & 39.82 & \\
\hline E. maxima & & 16 & 14.15 & \\
\hline
\end{tabular}

*Highly significant $(p<0.01)$

Table 4. Occurrence rate of Eimeria spp. in chicken in different management systems

\begin{tabular}{|c|c|c|c|c|}
\hline Management system & No. of samples examined & No. positive & \% positive & p-value \\
\hline Organised farms & 167 & 52 & 31.13 & \\
\cline { 1 - 4 } Backyard & 133 & 61 & 45.86 & \multirow{2}{*}{$\mathbf{0 . 0 0 2}^{*}$} \\
\cline { 1 - 4 } Total & $\mathbf{3 0 0}$ & $\mathbf{1 1 3}$ & $\mathbf{3 7 . 6 6}$ & \\
\hline
\end{tabular}

* Highly significant $(p<0.01)$

in Ethiopia, Amare et al. (2012) as well as Dinka and Tolossa (2012) reported a prevalence of $E$. tenella to be higher compared to $E$. necatrix, $E$. acervulina and E. brunetti.
In the study, the rate of occurrence of Eimeria infection was found to be higher in backyard poultry (45.86 per cent) compared to that in organised farms (31.13 per cent) (Table 

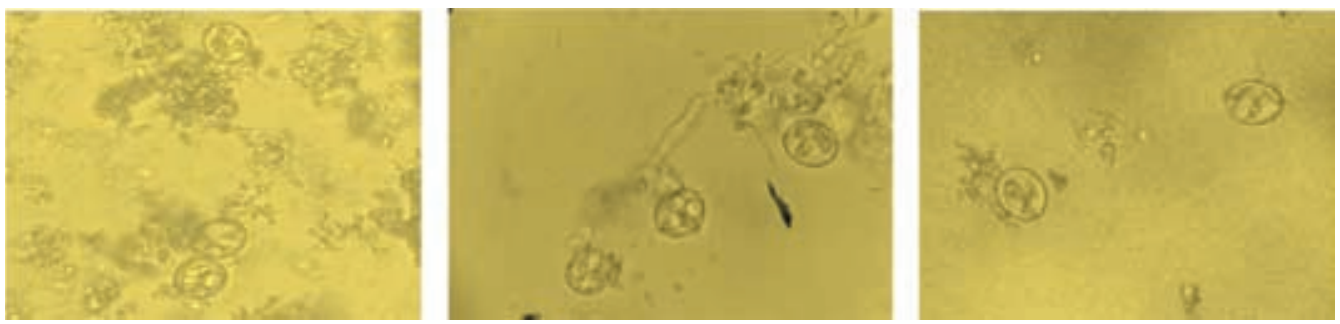

Fig.1. Sporulated oocysts of Eimeria spp.
A. Sporulated oocysts of
B. Sporulated oocysts of E. necatrix $\mathrm{X} 400$
C. Sporulated oocysts of E. maxima $\mathrm{X} 400$

4). Statistical analysis revealed significant association between the occurrence of coccidiosis and the type of management $(p<0.01)$. The findings were in accordance with Sharma et al. (2013) who recorded a higher prevalence rate for coccidiosis in backyard poultry $(53.61 \%)$ when compared to organised farms $(25.55 \%)$ in Jammu which was attributed to poor managemental practices and nonuse of anticoccidiostats. Similarly, Garbi et al. (2015) reported the higher rate of infection in backyard chicken $(27.6 \%)$ compared to chicken under intensive management system $(11.45 \%)$ in Ethiopia. The higher occurrence rate observed in backyard poultry in this study could be attributed to poor management practices and lesser use of anticoccidials in these birds. Moreover, the humid climatic conditions prevailing in the state favour rapid sporulation of oocysts and quick transmission of disease. However, Ketema and Fasil (2019) reported higher occurrence rate of coccidiosis in intensive management system (20.6\%) compared to that in backyard poultry $(17.9 \%)$ in Ethiopia and attributed it to the rearing of chicken in deep litter system, which provides optimal temperature and humidity for the sporulation of oocysts. Factors like overcrowding and water leakage also contributed to higher occurrence rate.

\section{Summary}

From the present study it could be summarised that the overall occurrence of Eimeria spp. in chicken was 37.66 per cent in and around Thrissur. The rate of infection was significantly higher in backyard poultry and the occurrence rate of $E$. tenella was found to be significantly higher compared to E. necatrix and E. maxima.

\section{Acknowledgement}

This study has been carried out as part of Master Research Program and the financial support provided by Kerala Veterinary and Animal Sciences University is acknowledged.

\section{Conflict of interest}

The authors declare that they have no conflict of interest.

\section{References}

Al- Gawad, A.A., Mahdy, O.A., El- Massary, A.A.N. and Al- Aziz, M.S.A. 2012. Studies on Coccidia of Egyptian balady breed chickens. Life Sci. J. 9: 568- 576.

Amare, A., Mengistu, A. and Nazir, S. 2012. Prevalence and aetiology of poultry coccidiosis and associated risk factor in white leghorn grower chicken at Kombolcha poultry farm, Ethiopia. J. WId's. Poult. Res. 2: 54 - 59.

Bhaskaran, M.S., Venkatesan, L., Aadimoolam, R., Jayagopal, H.T. and Sriraman, R. 2010. Sequence diversity of internal transcribed spacer-1 (ITS-1) region of Eimeria infecting chicken and its relevance in species identification from Indian field samples. Parasitol. Res. 106: 513-521.

Dinka, A. and Tolossa, Y.H. 2012. Coccidiosis in Fayoumi chickens at Debre Zeit

306 Occurrence of poultry coccidiosis in different management systems.. 
Agricultural Research centre poultry farm, Ethiopia. Eur. J. Appl. Sci. 4: 191 -195 .

Garbi, F., Tesfaye, A. and Woyessa, M. 2015. Study on prevalence of poultry coccidiosis in Nekemte town, East Wollega, Ethiopia. Afr. J. Agric. Res. 10: 328-333.

Gigi George, A. 1997. Prevalence, clinicopathology and control of coccidiosis in broiler chicken. M.V.Sc thesis, Kerala Agricultural University, Thrissur, 127p.

Jadhav, B.N., Nikam, S.V., Bhamare, S.N. and Jaid, E.L. 2011. Study of Eimeria necatrix in broiler chicken from Aurangabad District of Maharashtra state India. Int. Multidisciplinary Res. J. 1:11-12.

Ketema, E. and Fasil, N. 2019. Study on Prevalence and Associated Risk Factors of Poultry Coccidiosis in and Around Alage at vet College, Southwestern Ethiopia. Dairy and Vet. Sci. J. 11: 555805.
Khaier, M.A., Abdelhalim, A.I. and Abukashawa, S.M. 2015. Isolation and morphological identification of Eimeria tenella (Family: Eimeriidae) from Khartoum State (Sudan). J. Appl. Ind. Sci. 3: 177-181.

Rao V. P., Raman, M., Dhinakar, Raj, G., Abdul Basith, S. and Gomathinayagam, S. 2013. Multiple PCR aasay using SCAR primers to detect Eimeria species in chicken. J. Parasitol. Dis. 37: 110-113.

Sharma, S., Iqbal, A., Azmi, S. and Shah, H.A. 2013. Study of poultry coccidiosis in organized and backyard farms of Jammu region. Vet. WId. Res. 6: 467-469.

Soulsby, E. 1982. Helminths, Arthropods and Protozoans of domesticated animals, ( $7^{\text {th }}$ Ed.). Bailliere Tindall, London, UK. 809p. 